\title{
Effects of delayed feeding on survival and growth of summer flounder Paralichthys dentatus larvae
}

\author{
Gustavo A. Bisbal ${ }^{1, *}$, David A. Bengtson ${ }^{2}$ \\ ${ }^{1}$ Graduate School of Oceanography, University of Rhode Island, Narragansett, Rhode Island 02882, USA \\ ${ }^{2}$ Department of Zoology, University of Rhode Island, Kingston, Rhode Island 02881, USA
}

\begin{abstract}
Survival, growth, and starvation times were studied in summer flounder Paralichthys dentatus larvae hatched in the laboratory at 12.5 and $21^{\circ} \mathrm{C}$. The observations spanned the time interval from hatching throughout the period of feeding on rotifers. Survival and growth in length and weight were strongly dependent on water temperature and delay of the initial feeding. At either temperature, the percentage of summer flounder larvae surviving beyond the rotiter phase increased if food was made available at the time of mouth opening. At $12.5^{\circ} \mathrm{C}$, hatching started $85 \mathrm{~h}$ after fertilization. All feeding delays resulted in 2 separate periods of mortality, which caused low final survival. The point of no return ranged from 11 to $12 \mathrm{~d}$ after hatching. Larvae fed at mouth opening showed a maximum survival of $40 \%$. No significant growth in length or weight was evidenced by any group at $16 \mathrm{~d}$ after mouth opening. At $21^{\circ} \mathrm{C}$, hatching started $60 \mathrm{~h}$ after fertilization. Larvae fed at mouth opening showed $90 \%$ survival and significant growth in length and weight in $10 \mathrm{~d}$. A delay of $48 \mathrm{~h}$ in initial feeding led to a final survival of $36 \%$, but also resulted in significant growth. Time to the point of no return was 6 to $7 \mathrm{~d}$ from hatching. These results illustrate the interdependence of temperature and food availability and their effects on survival and growth of summer flounder larvae. These observations provide crucial information for the development of a culture system for this species and demonstrate the strong influence of the temperature-food relationship on larval survival and growth, suggesting that this relationship is a determinant of recruitment in certain areas of the ocean.
\end{abstract}

KEY WORDS: Starvation - Initial feeding - Larval development Pleuronectiformes · Flatfish

In the transition from consumption of endogenous reserves to active foraging, the acquisition of food becomes a critical priority for fish early-life-history stages. Hjort (1914) emphasized the concept that suc-

\footnotetext{
- Present address: Northwest Power Planning Council, Division of Fish and Wildlife, 851 S.W. Sixth Avenue, Suite 1100 Portland, Oregon 97204-1348, USA
}

cessful survival through the early larval stages - the so called critical period - could determine the yearclass strength of the adult stock (May 1974). Hjort's ideas were incorporated in subsequent postulates about the larvae-food interaction such as the the match-mismatch hypothesis (Cushing 1975) and the vertical stability hypothesis (Lasker 1978), among others. In every case, the main argument emphasizes the dominant role that chronic, cyclic, or sporadic environmental events play in yielding abundant food for the fish larvae or variable levels of starvation and mortality.

Temperature is also a primary environmental parameter which may limit the time larvae have to establish successful feeding by controlling the rate of metabolic demands and the pace at which yolk reserves are consumed (Brett 1970). The relationship between temperature and the onset of irreversible starvation has been evaluated in a number of marine fish larvae (Houde 1974, McGurk 1984). In general, larval survival and growth were reduced by either longer periods of early food deprivation at a single constant temperature, or by lower temperatures when the feeding delay interval was fixed. While death is an undisputable end result of food deprivation, it is possible to extract earlier subtle physiological information of ecological significance by establishing the 'point of no return' (PNR). This term defines the time beyond which larvae which failed to establish successful feeding would be unable to take up food (even if eventually available) and finally die (Blaxter \& Hempel 1963).

In the case of summer flounder Paralichthys dentatus larvae, several combinations of temperature and available food are possible, considering the spatial and temporal patterns of spawning and larval abundance (Smith 1973, Morse 1981, Able et al. 1990). The distri- 
bution of this species ranges from the Gulf of Maine to southeast Florida, USA, and the spawning cycle extends from September to April (Gilbert 1986). Early larvae of summer flounder are pelagic and have been collected at stations where temperatures ranged from 0 to $23.1^{\circ} \mathrm{C}$ (Smith 1973). Johns et al. (1981), however, showed that a temperature of $5^{\circ} \mathrm{C}$ was lethal to larvae during development in the laboratory.

Information on initial feeding is necessary, not only to understand the natural factors controlling prerecruit mortality in the wild, but also to reduce larval mortality in ongoing efforts to develop a commercial mass culture system for this species. This study was designed to determine the PNR in first-feeding summer flounder larvae as a consequence of delayed feeding at 2 temperatures $\left(12.5\right.$ and $\left.21^{\circ} \mathrm{C}\right)$. According to existing literature, these 2 temperatures are close to the minimum and maximum tolerance values of a viable thermal range for larvae of this species.

Materials and methods. Adult broodstock Paralichthys dentatus were collected from the wild at various locations in Narragansett Bay and Long Island Sound and held in laboratory facilities. Two separate spawnings, each from several males and a single female (but different females for the different temperatures) were artificially induced by repeated carp pituitary injections $\left(2.5 \mathrm{mg} \mathrm{kg}^{-1}\right)$ over 8 to $12 \mathrm{~d}$ following the methods of Smigielski (1975). Each egg mass was placed in a $38 \mathrm{I}$ glass tank covered on the outside by opaque black plastic. Each tank contained autoclaved, filtered $(10 \mu \mathrm{m})$ Narragansett Bay seawater (adjusted to $34 \pm 1 \%$ salinity by brine addition) maintained at a mean temperature of either $12.5 \pm 0.5$ or $21 \pm 1^{\circ} \mathrm{C}$. Aeration and overhead illumination adjusted to a $14 \mathrm{~h}$ photoperiod were provided. Antibiotic $(200 \mathrm{mg}$ erythromycin activity dissolved in $23 \mathrm{l}$ of water) was added to the water at the beginning. Water changes were performed several times to remove dead eggs and maintain water quality.

The combined effects of delayed feeding and temperature were experimentally observed on first-feeding flounder larvae. Newly hatched larvae were gently drawn into a glass tube and transferred into 21 containers at an initial density of 22 larvae $1^{-1}$. To each treatment (i.e. feeding schedule), 3 replicates of 44 larvae each were randomly assigned. Treatments in the trial at $12.5^{\circ} \mathrm{C}$ consisted of food being offered first at 4 (control), 5, 6, 8,9,10,11 or $12 \mathrm{~d}$ after hatching (DAH). At $21^{\circ} \mathrm{C}$, treatments consisted of food being offered first at 3 (control), 5, 6, 7, 8 or $9 \mathrm{DAH}$. Before food was offered for the first time, a sample of 15 larvae was taken from the original stocks for determination of initial standard length and dry weight. Every container was provided with individual mild aeration, covered with a translucent lid, and covered outside with black plastic. Dead larvae prior to mouth opening (initiation of the experiment) were assumed to be casualties of the handling procedure or other factors unrelated to feeding and were, thus, removed and replaced with new ones from the original stock kept at the same temperature.

Standard length of live larvae was measured under a dissecting microscope equipped with an ocular micrometer accurate to $0.7 \mu \mathrm{m}$. The larvae were rinsed in deionized water, placed in separate pre-weighed aluminum foil packets, dried at $60^{\circ} \mathrm{C}$ for at least $48 \mathrm{~h}$, and their individual dry weights recorded to the nearest $0.1 \mu \mathrm{g}$ with a Cahn C-31 electrobalance.

Rotifers (Brachionus plicatilis fed on the alga Tetraselmis suecica), and 1 initial addition of $T$. suecica were offered as food. Rotifers, and not natural zooplankton, were chosen as a standard food item in order to avoid changes in species composition during the study. This decision represents a trade-off between ecological realism and experimental (laboratory) practicality. The rotifer supply for those containers which had already received food was replenished daily as needed to maintain conditions of ad libitum rotifer rations. These conditions of unlimited prey were selected since the experiments were designed to measure the ability of larvae to establish feeding. Every morning, between 08:00 and 09:00 h, all the mortalities in each container were recorded and removed by pipette. The bottom of each container was siphoned every other day to remove very fine particles and about $250 \mathrm{ml}$ of fresh, autoclaved seawater were replaced. These procedures were cautiously performed to minimize external disturbance. The experiments were terminated when larvae in the original stock aquaria began to accept Artemia nauplii as their food item. Containers with less than 14 survivors were sampled completely for measurements of final lengths and dry weights as described above, while a subsample of 10 larvae was removed from containers with more than 14 survivors.

PNR was defined as the amount of time, expressed in days after hatching, at which $50 \%$ of the initial number of larvae were still alive, but unable to feed when food was made available and, thus, bound to die (Blaxter \& Hempel 1963). The PNR concept implies no recovery from starvation and its magnitude is not estimable in a statistical sense. Therefore, the time to reach $50 \%$ mortality had to be estimated by visual analysis of survival curves which would have reached $0 \%$ survival upon termination of the experiments. Survival curves from the different treatments were compared by a repeated measures analysis of variance (ANOVA), followed by a Fisher's protected L.SD test (Keppel 1982). Initial and final mean lengths and weights were statistically compared by a 1-way ANOVA followed by a Fisher's pro- 
Table 1. Paralichthys dentatus. Initial and final (after $16 \mathrm{~d}$ ) mean standard length (SL, mm) ( \pm SEM) and mean dry weight (DW, $\mu \mathrm{g})( \pm \mathrm{SEM})$ for summer flounder larvae raised at $12.5^{\circ} \mathrm{C}$ and fed on different days after hatching (DAH). n: container replicates (integer) or subsample drawn from the total survivors in each container (fraction). Means with the same exponent are not significantly different from each other

\begin{tabular}{|c|c|c|c|c|c|c|c|c|c|c|c|}
\hline \multicolumn{3}{|c|}{ Initial } & \multicolumn{3}{|c|}{4 DAH (control) } & \multicolumn{3}{|c|}{$5 \mathrm{DAH}$} & \multicolumn{3}{|c|}{$6 \mathrm{DAH}$} \\
\hline $\mathrm{n}$ & SL & DW & $\mathrm{n}$ & SL & DW & $\mathrm{n}$ & $\mathrm{SL}$ & DW & $\mathrm{n}$ & SL & DW \\
\hline \multirow[t]{3}{*}{$15 / 15$} & $\begin{array}{c}3.84 \\
(0.04)\end{array}$ & $\begin{array}{c}40.6 \\
(2.03)\end{array}$ & $10 / 24$ & $\begin{array}{c}5.39 \\
(0.16)\end{array}$ & $\begin{array}{l}123.7 \\
(12.45)\end{array}$ & $13 / 13$ & $\begin{array}{c}4.38 \\
(0.12)\end{array}$ & $\begin{array}{c}47.4 \\
(7.10)\end{array}$ & $10 / 18$ & $\begin{array}{c}5.30 \\
(0.30)\end{array}$ & $\begin{array}{l}127.5 \\
(26.03)\end{array}$ \\
\hline & & & $11 / 11$ & $\begin{array}{c}4.54 \\
(0.16)\end{array}$ & $\begin{array}{c}64.7 \\
(11.81)\end{array}$ & $10 / 20$ & $\begin{array}{c}4.89 \\
(0.24)\end{array}$ & $\begin{array}{c}84.7 \\
(18.05)\end{array}$ & $9 / 9$ & $\begin{array}{c}4.65 \\
(0.17)\end{array}$ & $\begin{array}{c}68.9 \\
(13.69)\end{array}$ \\
\hline & & & $10 / 18$ & $\begin{array}{c}4.54 \\
(0.15)\end{array}$ & $\begin{array}{c}70.8 \\
(9.66)\end{array}$ & & & & $5 / 5$ & $\begin{array}{c}4.59 \\
(0.30)\end{array}$ & $\begin{array}{c}61.9 \\
(21.63)\end{array}$ \\
\hline 1 & $\begin{array}{l}3.84^{\mathrm{ab}} \\
(0.0)\end{array}$ & $\begin{array}{r}40.6^{\mathrm{a}} \\
(0.00)\end{array}$ & 3 & $\begin{array}{r}4.82^{\mathrm{a}} \\
(0.28)\end{array}$ & $\begin{array}{c}86.5^{\mathrm{a}} \\
(18.72)\end{array}$ & 2 & $\begin{array}{c}4.64 \\
(0.26)\end{array}$ & $\begin{array}{c}66.1^{\mathrm{ab}} \\
(18.64)\end{array}$ & 3 & $\begin{array}{r}4.85^{\mathrm{a}} \\
(0.23)\end{array}$ & $\begin{array}{c}86.1^{d} \\
(20.80)\end{array}$ \\
\hline & $8 \mathrm{DAH}$ & & & $9 \mathrm{DAH}$ & & & $10 \mathrm{DAH}$ & & & $11 \mathrm{DAH}$ & \\
\hline $\mathrm{n}$ & SL & DW & $\mathrm{n}$ & SL & DW & $\mathrm{n}$ & SL & DW & $\mathrm{n}$ & SL & DW \\
\hline $12 / 12$ & $\begin{array}{c}4.87 \\
(0.16)\end{array}$ & $\begin{array}{c}63.0 \\
(9.45)\end{array}$ & $2 / 2$ & $\begin{array}{c}4.26 \\
(0.06)\end{array}$ & $\begin{array}{c}24.8 \\
(1.10)\end{array}$ & $4 / 4$ & $\begin{array}{c}4.19 \\
(0.06)\end{array}$ & $\begin{array}{c}38.1 \\
(3.99)\end{array}$ & $2 / 2$ & $\begin{array}{c}4.01 \\
(0.03)\end{array}$ & $\begin{array}{c}35.0 \\
(1.30)\end{array}$ \\
\hline $9 / 9$ & $\begin{array}{c}4.38 \\
(0.22)\end{array}$ & $\begin{array}{c}55.1 \\
(10.0)\end{array}$ & $10 / 10$ & $\begin{array}{c}4.28 \\
(0.08)\end{array}$ & $\begin{array}{c}28.1 \\
(3.83)\end{array}$ & $4 / 4$ & $\begin{array}{c}4.24 \\
(0.05)\end{array}$ & $\begin{array}{c}42.1 \\
(1.78)\end{array}$ & & & \\
\hline $1 / 1$ & $\begin{array}{c}3.56 \\
(0.15)\end{array}$ & $\begin{array}{c}27.5 \\
(9.66)\end{array}$ & $4 / 4$ & $\begin{array}{c}4.21 \\
(0.04)\end{array}$ & $\begin{array}{c}39.8 \\
(4.18)\end{array}$ & & & & & & \\
\hline 3 & $\begin{array}{r}4.27^{a} \\
(0.38)\end{array}$ & $\begin{array}{c}48.5^{\mathrm{a} b} \\
(10.77)\end{array}$ & 3 & $\begin{array}{r}4.25^{\mathrm{a}} \\
(0.02)\end{array}$ & $\begin{array}{r}30.9^{b} \\
(4.53)\end{array}$ & 2 & $\begin{array}{r}4.22^{\mathrm{a}} \\
(0.03)\end{array}$ & $\begin{array}{l}40.1^{a b} \\
(2.00)\end{array}$ & 1 & $\begin{array}{l}4.01^{\mathrm{a}} \\
(0.0)\end{array}$ & $\begin{array}{l}35.0^{\mathrm{ab}} \\
(0.00)\end{array}$ \\
\hline
\end{tabular}

tected LSD. The significance level to establish statistical differences was set at $\alpha=0.05$ in all operations.

Results. Hatching of summer flounder incubated at $12.5^{\circ} \mathrm{C}$ started $85 \mathrm{~h}$ after fertilization. At Day 0 of the experiment, larvae kept at this temperature averaged $3.8 \mathrm{~mm}$ in standard length while the mean dry weight was $40.6 \mu \mathrm{g}$ (Table 1). Final mean lengths and weights for each treatment were not statistically different from the initial measurements at mouth opening. Final mean weights of larvae fed at $4 \mathrm{DAH}$ (control) and $6 \mathrm{DAH}$, however, were significantly different from that of larvae first fed $9 \mathrm{DAH}\left[F_{0.05}(7,10)=2.0\right]$ (Table 1 ). During the $16 \mathrm{~d}$ of the experiment at $12.5^{\circ} \mathrm{C}$ growth in mean standard length ranged from 4 to $26 \%$, whereas growth in mean dry weight varied from a loss of $24 \%$ to a gain of $113 \%$ (Table 1 ).

The mortality pattern of all summer flounder larvae at $12.5^{\circ} \mathrm{C}$ was similar for all treatments with a low final survival value for each of them (Fig. 1A). Overall, these trends showed that the incidence of mortality was most intense during 2 periods: one from 4 to $6 \mathrm{DAH}$, and the other from 12 DAH onward. A maximum final survival of $40 \%$ was attained by larvae first fed $4 \mathrm{DAH}$, when the mouth first opened (control group). This value was statistically different from that of the 12 DAH group. The PNR at this temperature was estimated to be 11 to
$12 \mathrm{DAH}$, the time interval in which $50 \%$ mortality occurred for the only treatment (first fed at $12 \mathrm{DAH}$ ) showing $0 \%$ survival at the end of the experiment.

Hatching at $21^{\circ} \mathrm{C}$ started after approximately $60 \mathrm{~h}$ of incubation. Upon initiation of the experiment, larval mean standard length was $3.6 \mathrm{~mm}$ and mean dry weight $26.9 \mu \mathrm{g}$ (Table 2). Significant differences were detected in the final mean size of summer flounder larvae in the treatments at $21^{\circ} \mathrm{C}\left[F_{0.05}(3,6)=33.0\right]$ (Table 2). At $10 \mathrm{~d}$ after initiation of the experiment, the fed control group had grown a significant $49 \%$ in standard length and gained more than 5 times in dry weight. These figures were statistically higher than those attained by any other group. Larvae first fed $5 \mathrm{DAH}$ were also significantly longer (19\%) and heavier (159.5\%) than at mouth opening (Table 2).

Survival of summer flounder larvae maintained at $21^{\circ} \mathrm{C}$ was significantly affected by the feeding delay $\left[F_{0.05}(5,12)=84.7\right]$ (Fig. 1B). All treatments showed a rapid drop in survivorship between Days 6 and 8 except for those first fed 3 DAH. Larvae in this experiment reached the PNR at approximately 6 to $7 \mathrm{DAH}$. Mouth opening at this temperature occurred $3 \mathrm{DAH}$ and the final survival for the control group was approximately $90 \%$, significantly higher than in any other treatment. The result of $2 \mathrm{~d}$ of initial starvation (5 DAH) 


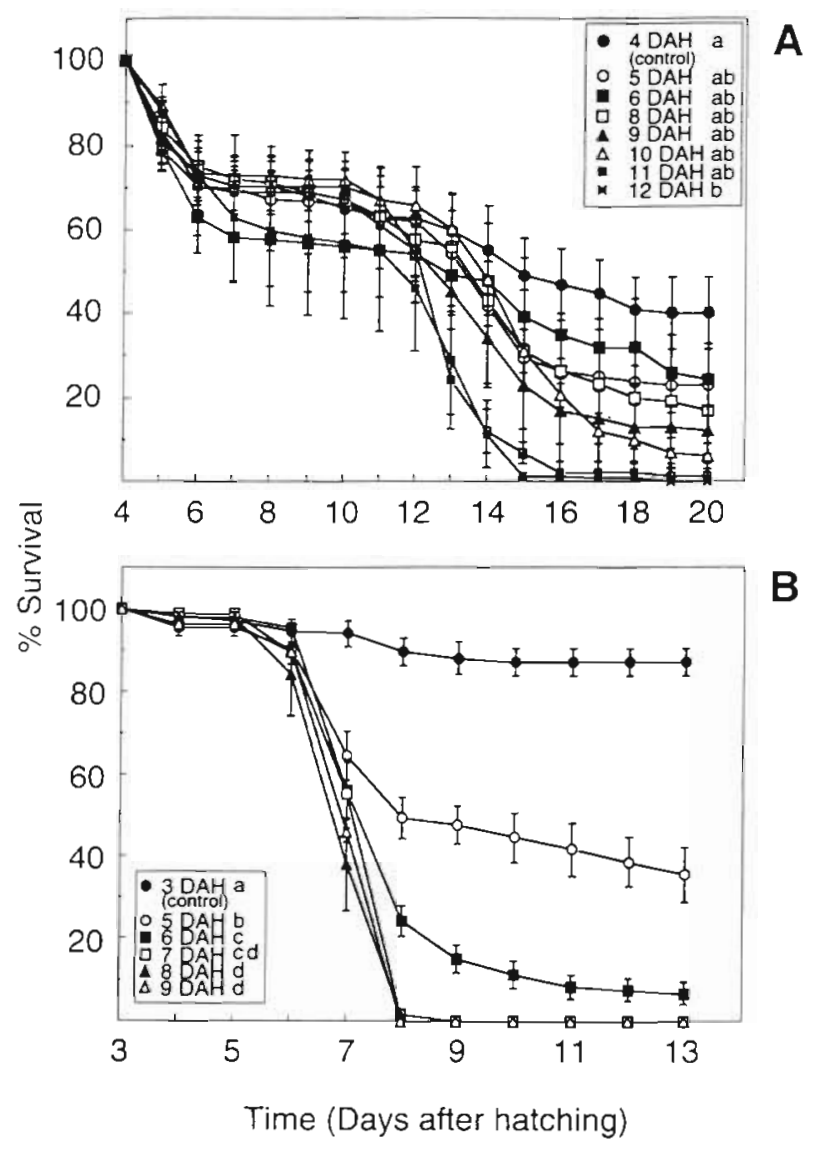

Fig. 1. Paralichthys dentatus. Survival curves for first-feeding summer flounder larvae raised at (A) $12.5^{\circ} \mathrm{C}$ and (B) $21^{\circ} \mathrm{C}$. Each curve traces the survival of a group fed on different days after hatching (DAH). Symbols indicate the mean number of survivors in 3 replicate containers \pm SEM. At each temperature, curves with the same letter are not significantly different from each other

was a final survival of $36 \%$, statistically higher than the remaining groups. Larvae first fed $6 \mathrm{DAH}$ also showed a significantly higher survival than those fed at later times.

Discussion. Fish larvae withstand starvation for longer times at lower temperatures where respiration losses due to basic metabolism, activity and yolk sac utilization are reduced (Blaxter \& Hempel 1963, Lasker et al. 1970, Jones 1972, Laurence 1978). The present experiments showed that summer flounder larvae possess sufficient reserves to survive starvation for approximately 6 to $7 \mathrm{~d}$ at a temperature close to the highest thermal linit reported to occur in their environment (Smith 1973), and they extend survivorship to between 11 and $12 \mathrm{~d}$ when the temperature is maintained close to the experimentally determined lower tolerance limit (Johns et al. 1981). Larval survival is also significantly affected by the time at which the larvae first have access to exogenous food. At both temperatures in this study, best survival was observed when the larvae began to feed at the time of mouth opening, which has also been previously observed in other flatfish species (Jones 1972, Houde 1974, Gadomski \& Petersen 1988).

Initiation of feeding is a function of the rate and efficiency at which the yolk sac material is consumed, which in turn depends on the incubation temperature. According to Buckley (1982) temperature is most significant in affecting the synchrony between completion of yolk sac absorption and initiation of feeding. In the case of summer flounder, the time to yolk sac resorption is 3 and $4.8 \mathrm{DAH}$ at 21 and $16^{\circ} \mathrm{C}$, respectively (Johns \& Howell 1980, Johns et al. 1981). At that time, the mouth and gut of the larvae are well developed to initiate prey capture (Johns et al. 1981, Bisbal \& Bengtson in press).

Although the experiments at both temperatures were conducted under essentially similar conditions, direct comparisons between them are risky since larvae for each experiment originated from eggs from a

Table 2. Paralichthys dentatus. Initial and final (after $10 \mathrm{~d}$ ) mean standard length (SL, mm) ( \pm SEM) and mean dry weight (DW, $\mu \mathrm{g})( \pm \mathrm{SEM})$ for summer flounder larvae raised at $21^{\circ} \mathrm{C}$ and fed on different days after hatching (DAH). $\mathrm{n}$ : container replicates (integer) or subsample drawn from the total survivors in each container (fraction). Means with the same exponent are not significantly different from each other

\begin{tabular}{|c|c|c|c|c|c|c|c|c|c|c|c|}
\hline & \multirow{2}{*}{$\begin{array}{l}\text { Initial } \\
\text { SL }\end{array}$} & \multirow[b]{2}{*}{ DW } & \multicolumn{3}{|c|}{$3 \mathrm{DAH}$ (control) } & \multicolumn{3}{|c|}{$5 \mathrm{DAH}$} & \multicolumn{3}{|c|}{$6 \mathrm{DAH}$} \\
\hline $\mathrm{n}$ & & & $\mathrm{n}$ & $\mathrm{SL}$ & DW & $\mathrm{n}$ & SL & DW & $\mathrm{n}$ & SL & DW \\
\hline \multirow[t]{3}{*}{$15 / 15$} & $\begin{array}{c}3.62 \\
(0.04)\end{array}$ & $\begin{array}{c}26.9 \\
(1.63)\end{array}$ & $10 / 38$ & $\begin{array}{c}5.33 \\
(0.14)\end{array}$ & $\begin{array}{l}144.5 \\
(9.93)\end{array}$ & $10 / 15$ & $\begin{array}{c}4.35 \\
(0.10)\end{array}$ & $\begin{array}{c}65.5 \\
(5.44)\end{array}$ & $3 / 3$ & $\begin{array}{c}3.70 \\
(0.10)\end{array}$ & $\begin{array}{c}40.5 \\
(12.47)\end{array}$ \\
\hline & & & $10 / 41$ & $\begin{array}{c}5.60 \\
(0.19)\end{array}$ & $\begin{array}{c}170.1 \\
(22.47)\end{array}$ & $10 / 21$ & $\begin{array}{c}4.49 \\
(0.13)\end{array}$ & $\begin{array}{c}80.4 \\
(7.15)\end{array}$ & $1 / 1$ & $\begin{array}{c}4.02 \\
(0.00)\end{array}$ & $\begin{array}{c}56.8 \\
(0.00)\end{array}$ \\
\hline & & & $10 / 36$ & $\begin{array}{c}5.28 \\
(0.17)\end{array}$ & $\begin{array}{c}127.2 \\
(13.12)\end{array}$ & $11 / 11$ & $\begin{array}{c}4.11 \\
(0.17)\end{array}$ & $\begin{array}{c}63.52 \\
(10.36)\end{array}$ & $5 / 5$ & $\begin{array}{l}4.18 \\
(0.16)\end{array}$ & $\begin{array}{c}51.6 \\
(8.67)\end{array}$ \\
\hline 1 & $\begin{array}{l}3.62^{\mathrm{a}} \\
(0.0)\end{array}$ & $\begin{array}{l}26.9^{\mathfrak{a}} \\
(0.00)\end{array}$ & 3 & $\begin{array}{c}5.40^{\mathrm{b}} \\
(0.10)\end{array}$ & $\begin{array}{c}147.3^{b} \\
(12.47)\end{array}$ & 3 & $\begin{array}{r}4.32^{c} \\
(0.11)\end{array}$ & $\begin{array}{r}69.8^{c} \\
(5.35)\end{array}$ & 3 & $\begin{array}{l}3.97^{\mathrm{d} r} \\
(0.14)\end{array}$ & $\begin{array}{c}49.6^{\alpha r} \\
(4.82)\end{array}$ \\
\hline
\end{tabular}


single female, different for each experimental batch, and sperm from several males. The original experimental design was started under the ideal situation of testing embryos from common parents raised at 21 and $10^{\circ} \mathrm{C}$. However, failure to observe hatching at $10^{\circ} \mathrm{C}$ forced us to repeat the low temperature experiment (this time at $12.5^{\circ} \mathrm{C}$ ) with larvae from different parents. This raises the possibility, therefore, that differences in survival between the 2 temperatures reflect differences in quality of eggs. The initial survival decline observed at $12.5^{\circ} \mathrm{C}$ could be a reflection of higher susceptibility of younger stages to low temperatures. The second mass mortality event at $12.5^{\circ} \mathrm{C}$ reflects the death of irreversibly starved larvae.

Growth in length and weight, and survival of summer flounder larvae were strongly dependent on temperature and delay of the initial feeding. At $12.5^{\circ} \mathrm{C}$ every treatment group was represented by a low number of survivors which did not grow significantly from the initial figures at mouth opening. Growth of larvae at $21^{\circ} \mathrm{C}$, on the other hand, was inversely proportional to the duration of early starvation. The size distribution of the survivors of the $21^{\circ} \mathrm{C}$ experiment shows an increase in mean size and weight when the initial feeding delay was shorter.

The close interaction between temperature and food availability demonstrated here has 2 immediate applications. The first is directly relevant to intended hatchery commercial production of summer flounder. Under those circumstances, conditions of food availability at mouth opening and high temperatures should be chosen since growth rates are higher and survival of up to $90 \%$ past the rotifer phase can be attained. The second application concerns an ecological argument. Roff (1981), in discussing the dependence of flatfish offspring survival on environmental factors, reviewed the case of several species in which the year-class strength is correlated with the average water temperature. For the specific case of summer flounder, a wide scope of annual thermal fluctuations is observable throughout its spatial and temporal ranges of distribution (Smith 1973, Morse 1981, Able et al. 1990). Considerations of the factors controlling recruitment variability in several North American flatfishes led Miller et al. (1991) to suggest the possibility that food limitation may operate as a controlling factor of recruitment in offshore areas at lower latitudes. When these postulates are connected with the present experimental results, an argument can be made that the interaction between temperature and available food in certain areas of the ocean will contribute to the production of larger and stronger summer flounder larvae than others. Only well-planned field sampling will provide the necessary evidence to accept or reject this hypothesis.
Acknowledgements. This research was supported by the United States Department of Commerce, National Oceanic and Atmospheric Administration, National Marine Fisheries Service, Saltonstall-Kennedy grant NA-90-AA-H-SK033. We thank Dr James Heltshe (US-EPA, Narragansett ERL) for his assistance in the statistical analysis and Drs Larry Buckley (NOAA/URI), Ted Durbin (URI), Perry Jeffries (URI) and Grace Klein-MacPhee (URI), for their helpful comments on this manuscript.

\section{LITERATURE CITED}

Able KW, Matheson RE, Morse WW, Fahay MP, Shepherd G (1990) Patterns of summer flounder Paralichthys dentatus early life history in the Mid-Atlantic Bight and New Jersey estuaries. Fish Bull US 88:1-12

Bisbal GA, Bengtson DA (in press) Development of the digestive tract in larval summer flounder, Paralichthys dentatus L. J Fish Biol

Blaxter JHS, Hempel G (1963) The influence of egg size on herring larvae (Clupea harengus L.). J Cons int Explor Mer 28:211-244

Brett JR (1970) Temperature - fishes. In: Kinne O (ed) Marine ecology, Vol 1. Wiley-Interscience, New York, p 515-616

Buckley LJ (1982) Effects of temperature on growth and biochemical composition of larval winter flounder Pseudopleuronectes americanus. Mar Ecol Prog Ser 8:181-186

Cushing DH (1975) Marine ecology and fisheries. Cambridge University Press, Cambridge

Gadomski DM, Petersen JH (1988) Effects of food deprivation on the larvae of two flatfishes. Mar Ecol Prog Ser 44: $103-111$

Gilbert CR (1986) Species profiles: life histories and environmental requirements of coastal fishes and invertebrates (South Florida). Southern, Gulf, and summer flounders. US Fish Wildl Serv Biol Rep 82(11.54), US Army Corps of Engineers, TR EL-82-4

Hjort $J$ (1914) Fluctuations in the great fisheries of northern Europe viewed in the light of biological research. Rapp P-v Réun Cons perm int Explor Mer 20

Houde ED (1974) Effects of temperature and delayed feeding on growth and survival of larvae of three species of subtropical marine fishes. Mar Biol 26:271-285

Johns DM, Howell WH (1980) Yolk utilization in summer flounder (Paralichthys dentatus) embryos and larvae reared at two temperatures. Mar Ecol Prog Ser 2:1-8

Johns DM, Howell WH, Klein-MacPhee G (1981) Yolk utilization and growth to yolk-sac absorption in summer flounder (Paralichthys dentatus) larvae at constant and cyclic temperatures. Mar Biol 63:301-308

Jones A (1972) Studies on egg development and larval rearing of turbot Scophthalmus maximus L. and brill Scophthalmus rhombus L. in the laboratory. J mar biol Ass UK 52:965-986

Keppel G (1982) Design and analysis. A researcher's handbook. Prentice Hall, Englewood Cliffs, NJ

Lasker R (1978) The relation between oceanographic conditions and larval anchovy food in the California Current: identification of factors contributing to recruitment failure. Rapp P-v Réun Cons int Explor Mer 173:212-230

Lasker R, Feder HM, Theilacker GH, May RC (1970) Feeding growth and survival of Engraulis mordax larvae reared in the laboratory. Mar Biol 5:345-353

Laurence GC (1978) Comparative growth, respiration and delayed feeding abilities of larval cod (Gadus morhua) 
and haddock (Melanogrammus aeglefinus) as influenced by temperature during laboratory studies. Mar Biol 50: $1-7$

May RC (1974) Larval mortality in marine fishes and the critical period concept. In: Blaxter JHS (ed) The early life history of fish. Springer-Verlag, New York, p 3-19

McGurk MD (1984) Effects of delayed feeding and temperature on the age of irreversible starvation and on the rates of growth and mortality of Pacific herring larvae. Mar Biol $84: 13-26$

Miller JM, Burke JS, Fitzhugh GR (1991) Early life history patterns of Atlantic North American flatfish: likely (and unlikely) factors controlling recruitment. Neth J Sea Res

This note was submitted to the editor

\section{$27: 261-275$}

Morse WW (1981) Reproduction of the summer flounder, Paralichthys dentatus (L.). J Fish Biol 19:189-203

Roff DA (1981) Reproductive uncertainty and the evolution of iteroparity: Why don't flatfish put all their eggs in one basket? Can J Fish Aquat Sci 38:968-977

Smigielski AS (1975) Hormone-induced spawnings of the summer flounder and rearing of the larvae in the laboratory. Prog Fish Cult 37:3-8

Smith WG (1973) The distribution of summer flounder, Paralichthys dentatus, eggs and larvae on the Continental Shelf between Cape Cod and Cape Lookout, 1965-1966. Fish Bull US 71:527-548

Manuscript first received: June 2, 1994

Revised version accepted: December 23, 1994 